\title{
Analysis of irrigation water tariffs and taxes in Europe
}

\author{
Julio Berbel ${ }^{\mathrm{a}, *}$, M. Mar Borrego-Marin ${ }^{\mathrm{a}}$, Alfonso Exposito ${ }^{\mathrm{b}}$, \\ Giacomo Giannoccaro ${ }^{\mathrm{c}}$, Nazaret M. Montilla-Lopez ${ }^{\mathrm{a}}$ \\ and Catarina Roseta-Palma ${ }^{\mathrm{d}}$
}

\author{
${ }^{a}$ WEARE: Water, Environmental and Agricultural Resources Economics, Department of Agricultural Economics, \\ University of Cordoba, Campus Rabanales. Ctra N-IV km396. Gregor Mendel Building, E-14071 Córdoba, Spain \\ *Corresponding author. E-mail: eslbevej@uco.es \\ ${ }^{b}$ Department of Economic Analysis, Universidad de Sevilla, Ramón y Cajal 1, 41018 Sevilla, Spain \\ ${ }^{c}$ Department of Agricultural and Environmental Science, University of Bari “Aldo Moro”, Via Amendola 165/A, \\ Bari 70126, Italy \\ ${ }^{d}$ Department of Economics and BRU-IUL, ISCTE-Instituto Universitário de Lisboa, Av. Forças Armadas, \\ 1649-026 Lisboa, Portugal
}

\begin{abstract}
Water taxation in European Union (EU) countries is adapted to local conditions and institutional trajectories and contains a variety of taxes and tariffs to finance water services and induce a higher use efficiency. After having clarified certain concepts, this work offers an overview of water taxes and tariffs charged for agricultural water use in several European Union member states, both in water-abundant areas and in water-scarce regions. Mediterranean countries, such as France, Portugal, Italy and Spain, have implemented different tax systems on agricultural water abstractions to recover the costs of the regulation, storage, and management of basin-level water services with various levels of cost recovery in accordance with the provision by the Water Framework Directive. France, Portugal, and Italy have implemented an abstraction tax applied to any water source (surface and groundwater) as an instrument to induce water saving and internalize environmental and resource costs in the irrigation sector. Despite these efforts, current taxation remains very low in the European context. On the other hand, Northern European countries (including the Netherlands, Germany and Denmark) have no fiscal instruments related to agricultural abstractions (neither for surface nor for groundwater resources).
\end{abstract}

Keywords: Water policy; Water pricing; Water services; Water tariffs; Water tax

\section{Introduction}

Environmental fiscal policy involves the use of taxation measures to enhance fiscal revenues and improve environmental goals simultaneously. Nordic European countries introduced environmental doi: 10.2166/wp.2019.197

C IWA Publishing 2019 
taxes in the early 1990s, and today almost $7 \%$ of tax revenues in the EU are classified as environmentally related. The effects of environmental taxes as policy instruments are well-documented in the economic and political literature (European Environment Agency, 2016).

Environmental taxes have four functions: (a) internalization of external costs, which requires the optimal tax rate to correspond to the social marginal cost imposed by the negative externality; (b) encouragement of behavioural changes, to reduce the consumption of resources, pollution or the generation of waste; (c) revenue raising, to finance environmental protection activities or other public objectives; and (d) improvement of environmental quality through any of the previously listed pathways. The Europe 2020 Strategy (EC, 2010) recommends that EU member states gradually abandon environmentally harmful subsidies, apply regulations and standards (as set by EU legislation) aimed at environmental protection, and use economic instruments for this purpose. Water taxation is explicitly mentioned as a relevant tool.

An environmental tax is the fiscal instrument whose tax base is a physical unit of something that has a proven, specific, negative impact on the environment. According to the European Environment Agency (2016), 'taxes' are unrequited in the sense that benefits provided by government to taxpayers are not normally in proportion to their payments. The terms 'tariffs' and 'fees' are commonly used to cover compulsory payments to general government or to bodies outside general government, such as environmental funds or water management boards. Examples include wastewater, abstraction and waste charges.

The Water Framework Directive (WFD) (EC, 2000) promoted the use of economic instruments (including taxes, tariffs and general charges) to induce changes in water demand and to reduce water pollution (Art. 9). The WFD defines water services as '(a) Abstraction, impoundment, storage, treatment and distribution of surface water or groundwater; and (b) Wastewater collection and treatment facilities which subsequently discharge into surface water' (Art. 5), and concludes that EU countries should 'provide adequate incentives for users to use water resources efficiently, and thereby contribute to the environmental objectives of the Directive'. Additionally, national water policies must ensure an 'adequate contribution of the different water uses, disaggregated into at least industry, households and agriculture, to the recovery of the costs of water services', thereby adding the concept of 'including environmental and resource costs' whose aim is to achieve a more efficient and sustainable use of water resources (EC, 2003).

After almost two decades of the WFD's approval, however, the evaluation and recovery of the environmental and resource costs that it advocates are still not implemented in a harmonized way throughout the EU (EC, 2015; Berbel \& Expósito, 2018). The lack of a consistent method provides proof of the fuzziness of the concept leading to some experts to advocate for its elimination (Gawel, 2014). However, several European countries have proposed an 'ecotax' as an instrument to partially internalize these non-financial costs. These taxes are analysed in later sections of this study. Influenced by European pressure for the application of Art. 9 of the WFD, countries such as Portugal have introduced a tax on water abstraction, while, for example, Italy (where this type of taxation is already applied) has made a commitment to volumetric taxation. Paradoxically, the Netherlands and Germany (State of Baden-Württemberg) eliminated such taxes in 2008 and 2011, respectively.

The use of water pricing in urban supply (i.e., domestic, commercial, industrial) is generalized in most EU member states despite its different levels of cost recovery in water services (EC, 2012, 2015). Irrigation is the most significant water consumer across the whole EU, specially in Mediterranean countries where average water use by irrigation represents $70 \%$ of total withdrawals. Despite this 
importance, the use of cost recovery and water pricing instruments in the irrigation sector is not well defined and information on their implementation remains scarce. This paper strives to fill this knowledge gap by showing how irrigation water taxation has moved from theory into practice in certain European regions and countries.

This paper aims to offer an overview of the complex taxation of irrigation water services in EU countries, and focuses on the specific cases of Spain, Italy, Portugal, France, the Netherlands, Germany and Denmark, which include different types of taxation instruments. The rest of the paper is organized as follows. The next section attempts to clarify the group of taxes and tariffs currently charged to water users, while focusing on irrigation. The specific case studies of the aforementioned European countries are then analysed in great detail. Subsequently, a brief comparative analysis of the irrigation water taxation in these countries is carried out. Due to its relevance in designing water taxation systems, the issue of cost-sharing between sectors is reviewed in a subsequent section. Finally, a brief discussion and concluding remarks are offered.

\section{Fiscal instruments of water services in the eu}

The design of fiscal instruments in water services is complex, thus leading to the mixing of different concepts, whether in academic, technical or dissemination publications: taxes, tariffs, public prices and other charges are applied to a variety of water users and services, as will be explained throughout the paper. Within taxation instruments in water services, environmental taxes stand out. While contributing towards raising revenue, they are mainly geared towards the attainment of environmental protection objectives. In this respect, the OECD has supported the consistent use of these instruments, and has offered an analysis regarding their implementation (OECD, 2010a). Regarding water pollutants, countries such as France, Belgium and Denmark have introduced taxes on pesticides. Other countries, such as Spain and Germany, are currently considering similar instruments.

Figure 1 offers a classification of these different fiscal instruments and presents an introductory vision of water taxation in Spain (which has some similarities with other EU countries, such as Portugal and France). Generally, cost-sharing between sectors served by multipurpose infrastructures (e.g., reservoirs, channels) is required since urban and irrigation users share infrastructures and resources. The figure is based on a complete compilation made by the Spanish Ministry of Environment (2007), but the specific configuration is an example of the different fiscal instruments that coexist in all regions of peninsular Spain (there is a special regime in the Canary Islands). The values $\left(€ / \mathrm{m}^{3}\right)$ correspond to average values of tariffs and taxes in 2015.

In particular: [1] Ecotax = An instrument for introducing environmental and resource costs; [2] Water Agency (or River Basin Authority, RBA) Tariff (Supply) = Financial cost recovery of capital and O\&M costs of public services (i.e., storage, transport and control); [3] Regional Government Tariff = Urban water tax earmarked to finance water infrastructures (mainly wastewater treatment (WWT); [4] Utility water tariff = Utility water price to recover costs of urban services (supply, sanitation and WWT); [5] Tariffs charged by water user associations (WUA) or multi-user supply systems $=$ User-based costsharing mechanism for internal WUA cost support; [6] Water Agency Tariff (Discharge) = Instrument earmarked to support WWT discharge control and policy.

As mentioned, tariffs (also named fees in official documents), unlike taxes, are related to the provision of a specific service. In the case of Spain, the 'canon' (or fee set by the Water Agency to recover financial costs of up-stream water infrastructures) and the water-use tariff are paid by irrigation users and levied on the 'particular benefit obtained from regulation water infrastructures or others made 


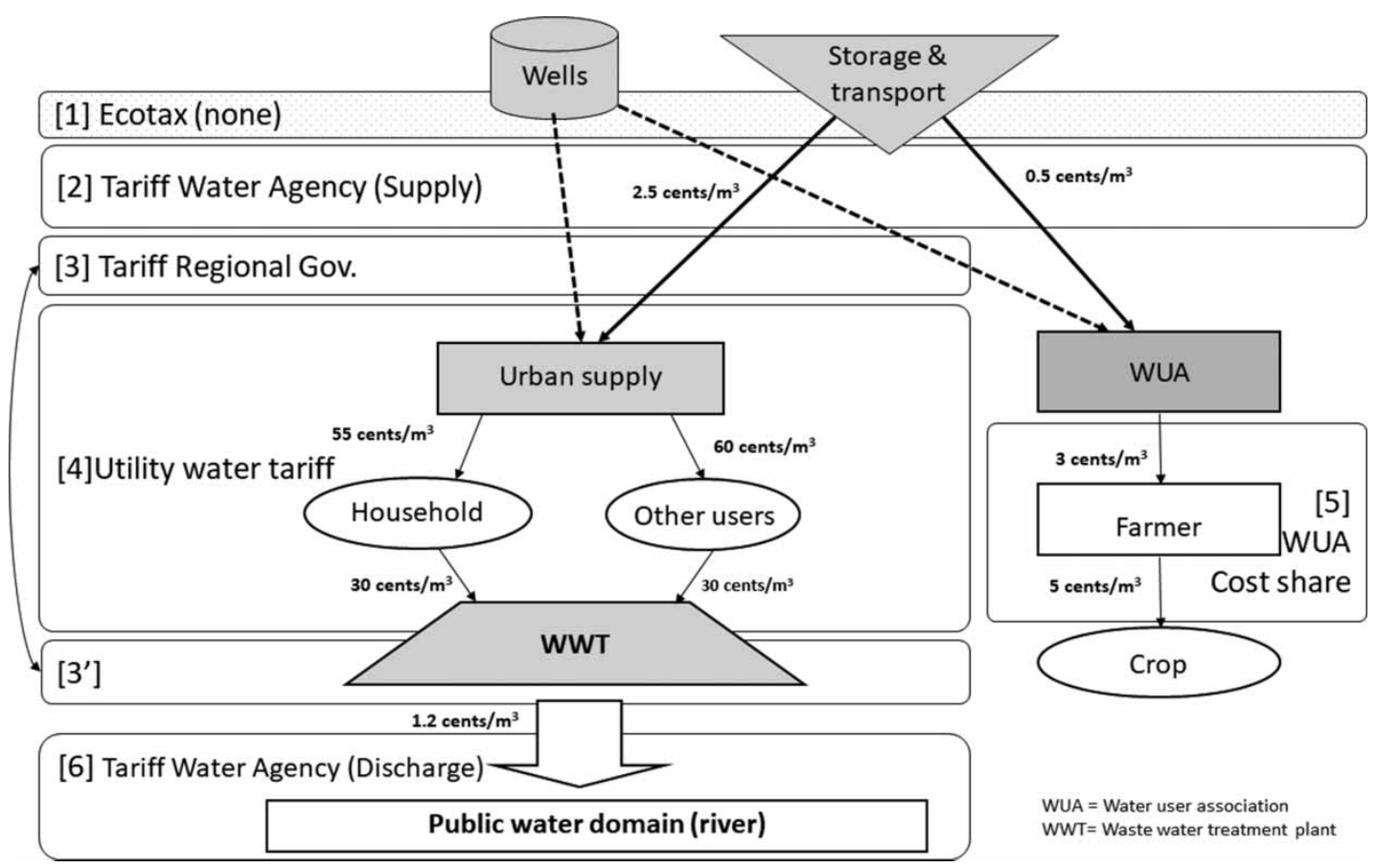

Fig. 1. Fiscal instruments in water services (Spain). Source: Authors' own.

by the State' (Art. 114, Spanish Water Law 2001). Furthermore, the Basin Water Agency pollution discharge control tariff (Art. 113) is limited to covering the cost of the regulation and control services. All these charges might be considered tariffs, regardless of their official denomination.

There are other relevant components in water taxation, such as the licence for groundwater abstraction, which is paid once in a lifetime in many countries or paid at regular intervals in the case of Italy. However, this charge has an administrative nature (as it only covers licensing administrative costs), generally not linked to the volume of water extracted or the provision of other water services. Enforcing an efficient water-pricing policy entails the metering and control of water uses and, as argued by several authors, the economic feasibility of volumetric pricing in agriculture is hindered by the high transaction costs incurred for irrigation water metering for self-supply groundwater users (Viaggi et al., 2010; Ursitti et al., 2018). Nonetheless, for shared irrigation systems, metering costs are probably similar to those for household meters. Finally, it should be noted that water discharges can also be subject to environmental taxes. In the case of Portugal, the national charge on water resources (TRH) includes a component for effluents. Nevertheless, it is more relevant in industry and urban networks than in agriculture, since there are no identifiable discharges in the irrigation sector (source of non-point pollution), although this instrument can be applied in the case of discharges related to livestock activities.

\section{Tax systems on irrigation in selected eu countries}

This section aims to offer a brief description of water taxation schemes in selected countries. The sample includes countries with greater water scarcity, located in southern Europe, such as Spain, 
Italy, France and Portugal, as well as countries where water abounds, such as Germany, the Netherlands and Denmark. The relevance of irrigation in each country is illustrated by the hydrological and agronomic indicators shown in Table 1.

As shown in Table 1, the irrigation context differs greatly between these countries, and indicates how the institutional trajectory has been influenced by both natural and socio-political conditions, which has led to the establishment of a variety of legal frameworks, which are reviewed below.

\section{Spain}

Seasonal rain patterns, evapotranspiration (ETP), highly variable annual rain and other variables are critical to explain the value of irrigation, which is not solely justified by average rainfall (see Table 1). Spain has an annual average rainfall of $611 \mathrm{~mm}$ which falls mostly outside the crop-growing season, and hence irrigation is a major feature of Spanish agricultural production. Surface waters are highly regulated, which is not the case with groundwater (20\% of irrigation water). Water governance and management are traditionally based on the existence of RBAs as main institutional bodies, which have regulation capacity on regulated surface waters, although they can achieve management agreements for non-regulated waters (e.g., river tributaries with no infrastructure) and groundwater. These features have led most taxation towards regulated surface waters, which are subject to tariffs with the following characteristics:

- Tariffs are generally based on land surface area and set by RBAs.

- Distribution of regulation costs is carried out by considering a 1:3 ratio of irrigation to urban costs (based on an assessment of 'theoretical benefits').

- Financial cost-recovery rate of $75 \%$ based upon the System of Environmental-Economic Accounting (SEEA-Water) methodology (Borrego-Marín et al., 2016).

- Groundwater use incurs no taxes (or tariffs related to the use of the resource).

- Users of non-regulated waters may be charged a partial tariff, albeit only in certain river basins (where it is considered 'indirect regulation'). In most cases, users frequently pay nothing. The average tariff in Spain is approximately $0.010 \mathrm{EUR} / \mathrm{m}^{3}$ (Spanish Ministry of the Environment, 2007, p. 166).

Table 1. Hydrological and irrigation indicators (2013).

\begin{tabular}{|c|c|c|c|c|c|c|c|}
\hline Country & $\begin{array}{l}\text { Average }^{\mathrm{a}} \\
\text { precipitation } \\
(\mathrm{mm})\end{array}$ & $\begin{array}{l}\text { Water abstraction } \\
\text { (\% renewable } \\
\text { resources) }\end{array}$ & $\begin{array}{l}\text { Irrigation } \\
\text { water use } \\
(\% \text { total })\end{array}$ & $\begin{array}{l}\text { Irrigated } \\
\text { area } \\
\text { (th. ha) }\end{array}$ & $\begin{array}{l}\text { Irrigated area } \\
(\% \text { cultivated } \\
\text { area })\end{array}$ & $\begin{array}{l}\text { Irrigation } \\
\text { water use } \\
\left(\mathrm{hm}^{3}\right)\end{array}$ & $\begin{array}{l}\text { Average } \\
\text { irrigation } \\
\left(\mathrm{m}^{3} / \mathrm{ha}\right)\end{array}$ \\
\hline Spain & 611 & 33 & 69 & 3,733 & 22 & 20,423 & 5,471 \\
\hline Italy & 942 & 18 & 49 & 2,866 & 24 & 13,770 & 4,804 \\
\hline France & 840 & $\mathrm{n} / \mathrm{a}$ & $25^{\mathrm{b}}$ & 1,424 & 5 & 2,437 & 1,712 \\
\hline Portugal & 820 & $\mathrm{n} / \mathrm{a}$ & 74 & 477 & 14 & 3,517 & 7,371 \\
\hline Germany & 750 & 3 & $\mathrm{n} / \mathrm{a}$ & 485 & 3 & 1,164 & 2,400 \\
\hline Denmark & 610 & 27 & $\mathrm{n} / \mathrm{a}$ & 448 & 17 & 179 & 400 \\
\hline Netherlands & 850 & 1 & $\mathrm{n} / \mathrm{a}$ & 565 & 29 & 170 & 300 \\
\hline
\end{tabular}

Source: Authors' own estimation based on Eurostat database and other sources.

${ }^{a}$ All Mediterranean countries (FR, ES, IT, PO) share large regional variation.

${ }^{\mathrm{b}}$ Refrigeration uses are excluded. 
Table 2 summarizes the taxation on regulated water resources. As shown, the irrigation sector contributes towards covering water service costs through two instruments: the tariff applied by the RBA for services upstream (designed to cover $100 \%$ of operating and maintenance costs and a significant proportion (but not all) of capital cost); and the tariffs charged by WUAs (or irrigation districts) to cover $100 \%$ of self-management downstream distribution costs. It should be mentioned that volumetric billing is compulsory for WUAs receiving subsidies from government and there is generalized use of measuring devices in WUAs that has induced some water savings as a percentage of the cost is linked to real consumption substituting the previous flat rate (per hectare) system (Berbel et al., 2019).

Italy

The case of Italy stands out for its characteristics as a Mediterranean country in which high rainfall occurs. Its average annual precipitation is greater than in France or the Netherlands and its rainfall is distributed more evenly throughout the year than in the Iberian Peninsula. These realities exert significant influence regarding its tax and the legal systems.

With an average annual rainfall of $942 \mathrm{~mm}$, hydroelectric use dominates the regulation of surface water in Italy. Water management is transferred to the regions, which are responsible for the design and implementation of water taxation, which includes that of the irrigation sector. Problems related to water drainage and sanitation were the origin of the 'Consorzio di Bonifica e Irrigazione' (Reclamation and Irrigation Board). These institutions were created to organize the drainage of temporary or annually flooded areas, although they later integrated supply functions into rural areas, mostly to irrigators.

These characteristics have led to a system based, on the one hand, on the Consorzio di Bonifica e Irrigazione services of drainage and supply and, on the other hand, on the regions and provinces that control non-regulated surface and groundwater resources. Two tax instruments exist: (i) tariff and (ii) tax for non-regulated waters and self-service (equally for surface and groundwater) abstractions.

The Consorzio di Bonifica e Irrigazione splits costs between drainage services (which is a public service, where excludability is difficult to enforce) and irrigation water supply to final users, where the agent who profits for water use can be identified. This duality makes cost distribution a complex task.

Table 2. Taxation on regulated water in Spain.

\begin{tabular}{lllc}
\hline & Characteristics & Cost-recovery rate & Self-supply (all sources) \\
\hline 1. Ecotax & None & $\mathrm{n} / \mathrm{a}$ & None \\
2. Water Agency Tariff & Royal Decree 144 & $\approx 64 \%$ & None \\
& $(1960)$, & & \\
& $\mu=0.012 € / \mathrm{m}^{3}$ & & Agriculture excluded \\
3. Regional Government Tariff & Agriculture excluded & $\mathrm{n} / \mathrm{a}$ & Agriculture excluded \\
4. Utility Water Tariff & Agriculture excluded & $\mathrm{n} / \mathrm{a}$ & Cost $\left(\mu=0.064 € / \mathrm{m}^{3}\right)$ \\
5. WUA Tariff & Self-management by & flat rate $\approx 73 \%$ of cost; & \\
& irrigators WUA & variable (volumetric) & \\
6. Water Agency Tariff (Discharge) & Agriculture excluded & $\mathrm{n} / \mathrm{a}$ & Agriculture excluded \\
\hline
\end{tabular}

Source: Authors' own. 
In the case where the Consorzio di Bonifica e Irrigazione supplies water under pressure (on demand) (see Table 3), there is a binomial tariff: (i) per hectare, plus (ii) volumetric charge. By contrast, there is no generalized volumetric rate in Italy for non-pressure water supply since the tariff is paid according to the irrigated land and is differentiated in terms of the crops according to their agronomic irrigation requirements (an overview of national features is reported in Zucaro et al., 2011). At the same time, the payment for drainage services is proportionally charged to the benefit attained (i.e., piano di classifica) and based on the hectares served. Each reclamation and irrigation board must recover its operational and maintenance costs, and the tariff charge varies according to the real cost of water supply. Regarding non-regulated surface and groundwater, the final users pay for all financial costs of water supply.

In Italy, the first regulation on water abstraction was established in 1933 (T.U. 1775/1933 Art. 35) by which all water sources fell into public domain. Nevertheless, a comprehensive environmental tax on water use whatever the type of supply services (collective or individual, public or private) has been lately enforced in 1994 (Art. 18, law n.36 5th January, 1994). The tax is based on the rate of flow withdrawal and is fixed on a regional scale differentiated according to its quality, whereby the general rate is multiplied by three if the extracted water presents drinking quality. Nevertheless, for agricultural purposes, metering is relatively unusual, and hence the tax for water abstraction is based on irrigable land. Lately, the Italian Government, under European Commission pressure, has taken a step forward in the direction of volumetric payment, which will be in operation in 2020.

The tax system in the Puglia region constitutes a relevant example for our study, since it involves the biggest sample of groundwater self-supply users in Italy. For comparison purposes, we assumed a farmer irrigated an area of 5 hectares with an average irrigation volume of $3,000 \mathrm{~m}^{3} /$ ha per year. Farmers pay a fixed component for access to a water source (abstraction licence valid for five years) while a variable component is paid per irrigable hectare; the latter has been interpreted as an 'ecotax' to internalize

Table 3. Cost to farmers for water abstraction in agriculture: Puglia region (2016).

\begin{tabular}{|c|c|c|c|c|}
\hline Supply services & Water costs & General & $\begin{array}{l}\text { Quality of } \\
\text { drinking water }\end{array}$ & Note \\
\hline \multirow{2}{*}{$\begin{array}{l}\text { Public and } \\
\text { collective } \\
\text { services }\end{array}$} & Tariff for water supply & \multicolumn{2}{|c|}{$\begin{array}{l}15 € / \text { ha; plus volumetric tariff } \\
\text { from } 0.12 \text { to } 0.70 € / \mathrm{m}^{3}\end{array}$} & Consorzio di Bonifica e Irrigazione \\
\hline & Tariff for drainage services & \multicolumn{2}{|c|}{$\begin{array}{l}\text { Applied on all farms (irrigated } \\
\text { and non-irrigated) }\end{array}$} & \\
\hline \multirow[t]{4}{*}{$\begin{array}{l}\text { On-farm private } \\
\text { self-supply }\end{array}$} & $\begin{array}{l}\text { General licensing fee for access } \\
\text { to water source }\end{array}$ & $20.4 € /$ year & & $\begin{array}{l}77 € \text { administrative fee }+25 € \text { of } \\
\text { Regional tax for renewal every } 5 \\
\text { years }\end{array}$ \\
\hline & Water use 'ecotax' & $0.36 € /$ ha & $1.09 € / \mathrm{ha}$ & $\begin{array}{l}\text { Minimum charge per user } 2.58 € / \\
\text { year }\end{array}$ \\
\hline & $\begin{array}{l}\text { Estimated environmental and } \\
\text { resource cost for the farmer }\end{array}$ & $0.0015 € / \mathrm{m}^{3}$ & $0.0017 € / \mathrm{m}^{3}$ & Resource tax \\
\hline & $\begin{array}{l}\text { Costs of self-supply } \\
\quad \text { (groundwater pumping) }\end{array}$ & \multicolumn{2}{|c|}{$\begin{array}{l}\text { Ranging from } 0.25 \text { to } 0.50 € / \\
\mathrm{m}^{3}\end{array}$} & No drilling costs included \\
\hline
\end{tabular}

\footnotetext{
${ }^{\mathrm{a}}$ For a farm size of 5 ha and irrigation volume of $3,000 \mathrm{~m}^{3} / \mathrm{ha}$. In the case of public collective services, water tariff includes the water fee for abstraction, while for self-supply the farmer pays the ecotax and the pumping costs. Source: Authors' own based on a report from University di Bari ‘Aldo Moro', Department of DiSAAT.
} 
environmental and resource costs. Moreover, licensing renewal involves additional costs for technical expertise (i.e., geological and agronomic) which makes the administrative procedure even more costly. To the best of our knowledge, Puglia region represents a unique case in Italy, where the renewal of water rights has been shortened below the general 20-year licensing period.

The Italian Government plans to implement a volumetric tariff system for all users (i.e., collective and self-supply) with the aim to recover environmental and resource costs as defined by the Decree of Ministry of Environment no. 39/2015. Nevertheless, the command and control approach has generally prevailed since water access and discharge rights are subject to licensing issued by Regional Government, which has the power to approve and revoke them unilaterally. Regarding environmental costs, these are avoided through a control of water withdrawals and discharges. This approach fails in the case of non-point pollution, as it is the case of agricultural fertilizers for which vulnerable zones have been established according to the European nitrogen directive (91/676/CEE).

\section{Portugal}

In the case of Portugal, its average rainfall is close to that of France (whose values lie between those of Spain and Italy) but there are significant differences between northern and southern regions. The average annual rainfall for the whole country is $820 \mathrm{~mm}$, but regional values range from less than $400 \mathrm{~mm}$ to over $3,000 \mathrm{~mm}$. As in Spain, RBAs carry out the planning of water resources, although in terms of water taxation certain differences must be pointed out. The Portuguese tax system is based on two fiscal instruments:

(1) Tax (referred to as a national charge on water resources or TRH), created in 2008 through DecretoLei no. 97/2008, to be applied to all water services, and covers abstractions including self-service and groundwater across the whole country. The TRH also covers pollution, occupation, extraction of inert aggregates and non-consumptive use. The revenue from the TRH currently goes towards the National Environment Fund (50\%) and the Portuguese Environment Agency (50\%).

(2) Cost-recovery of water regulation infrastructure through tariffs on water use, with the goal of increasing cost-recovery rates.

Table 4 summarizes the components of water pricing in Portugal, using the Empreendimento de Fins Múltiplos do Alqueva (EFMA), which is the largest irrigation system in the country, as an example. The first part is the TRH, which is a general charge applicable to all uses, albeit with use-specific values, and which combines six additive components. Two of these components apply to irrigation: 'A' for water abstraction from the public domain and ' $U$ ' for all waters subject to planning. Irrigation users with less than $3.7 \mathrm{~kW}$ pumping capacity are exempted from the TRH, and the legislation prescribes adjustments for water-scarce areas, metered water and large irrigation systems. For comparison, Table 4 includes the urban sector, who pays the highest TRH charge. The last rows in Table 4 show the per ha tariffs charged to irrigators, which are much higher values.

\section{France}

Despite major climatic heterogeneity in the case of France, rainfall is relatively high and evapotranspiration is low, and hence irrigation is used as a supplementary measure (average irrigation dose 
Table 4. Taxation on water abstraction (EFMA, 2018).

\begin{tabular}{lll}
\hline Water taxation $\left(€ / \mathrm{m}^{3}\right)$ & General & Scarcity zone \\
\hline TRH (component 'A') irrigation & $0.0032 \times 0.75^{(*)}$ & $\times 1,2$ \\
TRH (component 'U') irrigation & 0.00066 & - \\
Total TRH irrigation & 0.00306 & 0.00354 \\
TRH (component 'A') urban & $\mathbf{0 . 0 1 5}$ & $\times \mathbf{1 . 2}$ \\
TRH (component 'U') urban & 0.0031 & - \\
Total TRH urban & 0.0181 & 0.0211 \\
Per hectare conservation tariff (EFMA, low pressure) & $20 € / \mathrm{ha}$ & \\
Volumetric water supply tariff (EFMA; low pressure) & $0.032 € / \mathrm{m}^{3}$ &
\end{tabular}

Sources: For TRH, Decreto-Lei no. 46/2017 de 3 de m aio, available at https://dre.pt/application/file/a/106960830; for tariffs, EFMA pricing as defined in Despacho no. 3025/2017, available at: https://dre.pt/application/conteudo/106867751.

(*) For multipurpose dams such as EFMA, there is a $25 \%$ reduction (Art. 32, no. 2). Individual farmers who have meters can have an additional $10 \%$ reduction in both the $\mathrm{A}$ and the $\mathrm{U}$ components.

applied is approximately $2,000 \mathrm{~m}^{3} / \mathrm{ha}$ ). With an annual average rainfall of $840 \mathrm{~mm}$, the irrigation sector accounts for $25 \%$ of water withdrawals (excluding the cooling of power plants). The use of groundwater represents $50 \%$ of total irrigation withdrawals. Similar to Spain and Portugal, individual RBAs carry out the resource planning for the whole country, although the water taxation system is designed at a national level.

Specifically, the French case is based on a taxation system that charges water abstraction on a differentiating scheme based on origin (surface or groundwater), uses (irrigation, refrigeration, etc.) and zones (with extra charges in areas with scarce resources due to overexploitation). According to the French Water Law of 2006, although RBAs are responsible for the implementation of taxation on water abstractions, the national Parliament sets maximum ceilings (at national level) with a higher taxation for areas with resource shortages compared that for normal areas. Currently, this tax ceiling for irrigation stands at around $0.072 \mathrm{EUR} / \mathrm{m}^{3}$. Nevertheless, the final tax rate applied in each river basin is set by the Water Agency (or RBA).

Table 5 summarizes the case of the river basin of 'Rhône-Méditerranée et Corse', characterized as having one of the highest taxes on agriculture. This river basin has 265,000 irrigated hectares with an average water use of $3,300 \mathrm{~m}^{3} / \mathrm{ha}$, of which surface water represents $70 \%$. The reality, as shown in Table 5, is that the rate currently applied is much lower than the legal maximum (10\% on the tax ceiling).

\section{The Netherlands}

Although water management in the Netherlands has traditionally been aimed at securing water supplies and flood protection, quality issues and groundwater scarcity have risen in relevance in recent decades (Bass \& Graveland, 2011). Water Boards (Waterschappen) are the institutions in charge of managing water within regional catchment areas, whereas provincial and municipal governments manage groundwater resources. Following the environmental taxing wave in the 1990s, the Netherlands implemented a groundwater tax (GWT) in 1995 through the Environmental Taxes Act of 1994, with the aim of protecting the groundwater resource, which represents $70 \%$ of total water supply (the remaining $30 \%$ is extracted from bodies of surface water) (EEA, 2011). Annual precipitation 
Table 5. Taxation on water abstraction (Rhône Méditerranée river basin, 2018).

\begin{tabular}{|c|c|c|c|}
\hline Water use & Zone/Water type & & $\mathrm{EUR} / \mathrm{m}^{3}$ \\
\hline \multirow[t]{2}{*}{ General irrigation } & Normal & $\begin{array}{l}\text { Surface } \\
\text { Groundwater }\end{array}$ & 0.0072 \\
\hline & Scarcity & $\begin{array}{l}\text { Surface } \\
\text { Groundwater }\end{array}$ & 0.0144 \\
\hline \multirow[t]{2}{*}{ Gravity irrigation } & Normal & $\begin{array}{l}\text { Surface } \\
\text { Groundwater }\end{array}$ & 0.0010 \\
\hline & Scarcity & $\begin{array}{l}\text { Surface } \\
\text { Groundwater }\end{array}$ & 0.0020 \\
\hline \multirow[t]{2}{*}{ Other economic uses (general) } & Normal & $\begin{array}{l}\text { Surface } \\
\text { Groundwater }\end{array}$ & $\begin{array}{l}0.0054 \\
0.0097\end{array}$ \\
\hline & Scarcity & $\begin{array}{l}\text { Surface } \\
\text { Groundwater }\end{array}$ & $\begin{array}{l}0.0216 \\
0.0216\end{array}$ \\
\hline \multirow[t]{2}{*}{ Urban (potable water) } & Normal & $\begin{array}{l}\text { Surface } \\
\text { Groundwater }\end{array}$ & $\begin{array}{l}0.0300 \\
0.0466\end{array}$ \\
\hline & Scarcity & $\begin{array}{l}\text { Surface } \\
\text { Groundwater }\end{array}$ & 0.0683 \\
\hline
\end{tabular}

Source: JORF no. 0244 of 19th October, 2016.

Note: Payment exemption for uses below $10,000 \mathrm{~m}^{3} /$ year.

is $900 \mathrm{~mm}$. The area irrigated in the Netherlands is approximately 486,000 ha, which represents $25 \%$ of the cultivated area (Eurostat, 2010).

GWT interacted with existing provincial groundwater fees (PGFs) which paid for local groundwater management, thus GWT was designed more as a cost-recovery tax than a green tax, since PGFs have already targeted environmental outcomes (Schuerhoff et al., 2013). Extractors have paid PGFs since 1986 and they differ between provinces. Since groundwater is generally cheaper to extract than surface water, the GWT was introduced in order to narrow the price differential (Ekins, 1999). However, surface water is more expensive to clean for use, and this effect was therefore limited. The standard tax rate was $0.20 \mathrm{EUR} / \mathrm{m}^{3}$, mainly applied to water companies. Agriculture and industry uses faced a reduced rate of $0.08 \mathrm{EUR} / \mathrm{m}^{3}$ and its collection was distributed between urban uses (80\%), industry (19\%) and agriculture $(1 \%)$. Nevertheless, if less than $40,000 \mathrm{~m}^{3}$ per year was extracted, irrigated land was exempted, meaning that in practice this sector was not subject to said tax (Schuerhoff et al., 2013). In 2008, agriculture was totally exempted and regarding non-agricultural uses, there were exemptions for small users so that in practice almost only water utilities pay the tax. This fact, the lack of monitoring of groundwater impacts, and the diversion of revenues to the general budget instead of financing environmental objectives puts the efficiency for groundwater management into doubt, thereby leading to its complete abolishment in 2012.

Currently, groundwater users still pay the provincial fee (PGFs) in order to cover the costs of monitoring and controlling groundwater quality. Nevertheless, these fees are paid almost exclusively by large users (i.e., cities, industries and population agglomerations), and amount to $0.03 \mathrm{EUR} / \mathrm{m}^{3}$ on average. Irrigation is important in the Netherlands in some critical events such as the drought in the northern Europe as an EU Commissioner declared recently ${ }^{1}$ 'The severe drought experienced by many countries,

\footnotetext{
${ }^{1}$ Speech by Commissioner Phil Hogan at Opening of Wageningen University Academic Year 3 September 2018.
} 
including the Netherlands, has given us a timely reminder of the urgency of the crisis. The drought dried Dutch rivers and destroyed Dutch crops, mainly corn and potatoes. Farmers worked throughout the night to save anything they could and irrigate as much as possible'. In a scenario of climate change and higher hydrological uncertainty, it seems clear that irrigation water use will become a more important source of pressures and conflicts in the future.

\section{Germany}

Germany is a highly industrialized, intensively farmed and densely populated country, where water resources are subject to a variety of utilization requirements and major burdens. Of Germany's surface, $47 \%$ (16.7 million ha) is used for agriculture (BMUB, 2016). The level of precipitation varies regionally; although it tends to rain more in the West than in the East (e.g., Berlin/Brandenburg receives $590 \mathrm{~mm}$ per year; in Baden-Württemberg this is $938 \mathrm{~mm}$ per year).

Municipal regulations and the water laws of the different federal states stipulate that water supply and wastewater disposal is usually an obligation of the municipalities. Thus, the Local Rates Acts and municipal regulations of the federal states determine the framework for the calculation of charges for water services. Despite tariffs for municipal water use, drinking water and wastewater tariffs are additionally increased by special state taxes, such as the water abstraction tax and the wastewater tax. The utilities pay these state taxes to their respective federal states and have to invoice accordingly through the water and wastewater charges. This is the case in 13 German federal states (BMUB, 2016). These taxes apply only to household and industrial sectors. Agriculture is thus totally exempted from paying any of these municipal/state charges regarding the water abstraction of any surface and ground waters.

Depending on the federal state, the income generated by the water taxes is also used to support different areas (e.g., ecological measures that primarily focus on the protection and restoration of bodies of water, the maintenance of dykes or investment in flood protection). In certain states, the income is not tied to a special statutory purpose. In addition, in some federal states, farmers receive compensation payments for water-friendly management in water protection areas or catchment areas of water abstraction plants (e.g., Baden-Württemberg). These costs also form part of the water charges supported by other sectors.

The federal state of Baden-Württemberg (southwestern Germany) approved the state abstraction charge in 1988 by the Law on Protection of Compensatory Areas and Payments (Möller-Gulland et al., 2015), which was reformed in 2001 and 2011. This law implemented the payment of a volumetric tax of $0.005 \mathrm{EUR} / \mathrm{m}^{3}$ for general uses (theoretically including agriculture) and $0.025 \mathrm{EUR} / \mathrm{m}^{3}$ for urban uses. Nevertheless, this tax initially left small consumers, who were mostly farmers, exempt. Since 2011, agriculture as a whole has officially ceased to be subject to this tax (Möller-Gulland et al., 2015), as is the general case across Germany.

\section{Denmark}

With an irrigable area of around 450,000 ha, agriculture in Denmark faces problems related to quantitative excess and diffuse pollution. However, given the sandy nature of its many soils, there may be occasional irrigation during dry summers. Denmark is characterized by the high commitment of the state with guaranteeing groundwater quality, since $100 \%$ of urban consumption has this origin. To guarantee this objective, the national hydrogeological service (GEUS) covers the costs of its surveillance and control services with a tax paid only by urban users. In 2010 , this tax was $0.01 \mathrm{EUR} / \mathrm{m}^{3}(0.07 \mathrm{DKK})$ and 
was included in the price of urban water (GEUS, 2010) since it affects service supply. The tax rate is much lower than that in the Netherlands since this includes additional water services unrelated to surveillance and control of groundwater, and agriculture is exempted, with the cost of controlling diffuse pollution supported by urban users (GEUS, 2010). The tax on the use of pesticides and agrochemicals is an 'ecotax' that strives to apply the principle of the polluter pays. Nevertheless, it is worth noting that the national strategy for diffuse water pollution abatement consists of a policy mix of vaious instruments. Apart from taxation instruments, a significant role has been played by command and control measures, fertilizer accounting and zone-based manure incentives (Albiac, 2017).

\section{Other EU members}

In the rest of the EU, certain countries have implemented a water abstraction tax (e.g., Estonia, Finland, Sweden), although irrigation is generally exempted. Only the UK (now exiting the EU) taxes irrigation abstractions. Several eastern countries (e.g., Hungary, Romania) are implementing taxation schemes to the irrigation sector, although available data are scarce (ARCADIS, 2012).

\section{Brief comparative analysis of irrigation water taxation in the countries selected}

\section{Analysis of irrigation water tax and tariffs}

This section offers a brief comparative analysis of taxes and tariffs on irrigation water for the European countries selected. Financial cost-recovery rates in the irrigation sector are usually below $100 \%$, as illustrated in Table 6, although the principle of financial cost recovery is, in fact, included in the fiscal

Table 6. Comparison of taxes, tariffs, and cost recovery in irrigation sector.

\begin{tabular}{|c|c|c|c|c|c|c|c|c|c|}
\hline \multicolumn{4}{|l|}{ Eco tax } & \multicolumn{6}{|c|}{ Public infrastructure and services cost recovery ${ }^{\mathrm{a}}$} \\
\hline Country & Year & $€ / \mathrm{m}^{3}$ & Note & Year & Level & Agric. ${ }^{b}$ & $\begin{array}{l}\text { Capital } \\
\text { cost } \\
\text { recovery }\end{array}$ & $\begin{array}{l}\mathrm{O} \& \mathrm{M} \\
\text { cost } \\
\text { recovery }\end{array}$ & $\begin{array}{l}\text { Total cost } \\
\text { recovery }\end{array}$ \\
\hline Spain & - & No & $\mathrm{c}$ & 1960 & $\mathrm{RBA}$ & $54 € /$ ha & $56 \%$ & $\approx 100 \%$ & $\approx 85 \%$ \\
\hline Italy & 1994 & 0.0015 & $\times 3$ quality & 1933 & C. Bonifica & $36 € /$ ha & $\mathrm{n} / \mathrm{a}$ & $\mathrm{n} / \mathrm{a}$ & $\mathrm{n} / \mathrm{a}$ \\
\hline Portugal & 2017 & 0.00386 & $\begin{array}{l}\times 1.2 \\
\text { scarcity }\end{array}$ & 2015 & EFMA & $20 € / \mathrm{ha}+0.032 € / \mathrm{m}^{3}$ & $23 \%$ & $\approx 100 \%$ & $65 \%$ \\
\hline France & 2005 & 0.005 & $\times 2$ scarcity & 2005 & Canal & $36 € / \mathrm{ha}+0.07 € / \mathrm{m}^{3}$ & $15-60 \%$ & $\approx 100 \%$ & $\approx 85 \%$ \\
\hline Netherlands & $\begin{array}{c}\text { From } 1995 \\
\text { to } 2008\end{array}$ & 0.0001 & $\begin{array}{l}\text { Agric. } \\
\text { Exempted }\end{array}$ & 1997 & Provincial & $>150.000 \mathrm{~m}^{3}$ & $\approx 100 \%$ & $\approx 100 \%$ & $\approx 100 \%$ \\
\hline $\begin{array}{l}\text { Germany } \\
\text { (BW) }\end{array}$ & $\begin{array}{c}\text { From } 1988 \\
\text { to } 2011\end{array}$ & 0.005 & $\begin{array}{l}\text { Agric. } \\
\text { exempted }\end{array}$ & $\mathrm{n} / \mathrm{a}$ & $\mathrm{n} / \mathrm{a}$ & $\mathrm{n} / \mathrm{a}$ & $\mathrm{n} / \mathrm{a}$ & $\mathrm{n} / \mathrm{a}$ & $\mathrm{n} / \mathrm{a}$ \\
\hline
\end{tabular}

Source: Authors' own.

${ }^{\mathrm{a}}$ Cost-recovery level according to WFD EU member state implementation reports.

${ }^{\mathrm{b}}$ Most frequent value based on (OECD, 2010a).

${ }^{\mathrm{c}}$ The general rule in Spain is that of no taxation on GW resources. Berbel et al. (2018) discuss a singular case study that applies a GW tariff. 
regulations of water services in many EU countries. As an example, in Spain, municipal public services, which include water supply and sanitation, should not register financial deficits, thus imposing the obligation of full financial cost recovery for urban supply and sanitation. In the case of irrigation, the relevant administration is that of the RBAs, who recover $85 \%$ of total financial costs with $100 \%$ of the cost for operation and maintenance, and partly cover the capital cost (estimated at 56\% in the Libro Blanco del Agua, Spanish Ministry of Environment, 2000). Down-stream services supplied by WUAs are recovered 100\% (Borrego-Marín et al., 2016).

Table 6 shows the extent of water abstraction taxes and tariffs incurred by water authorities (i.e., RBA, Region, State, depending on each case). The analysis excludes irrigation district/WUA tariffs employed to recover costs of down-stream distribution services on a cost-sharing basis (usually selffinanced or with $100 \%$ cost recovery). As shown in Table 6, heterogeneity among EU countries remains high, especially regarding the service tariffs fixed by water authorities (normally to cover capital and O\&M costs of water infrastructure). With respect to water abstraction taxes, these are currently applied in only three countries, although their values remain very low.

The cost-recovery level is based upon the self-declaration contained in the Programme of Measures (PoM) of River Basin Management Plans (RBMP) approved by each country. The Netherlands declares that water services reach a $100 \%$ cost-recovery rate based upon the existing provincial groundwater control tax although irrigation is largely exempt from this instrument. In contrast, Mediterranean countries, such as Spain, Portugal and France, include agriculture in the financial recovery analysis.

Table 6 summarizes the various taxation instruments described in the previous section and classified as general abstraction taxes and tariffs on regulated resources. Several EU countries have introduced a differentiated taxation (as a multiplying factor), whose aim is to internalize the environmental and resource costs. This is the case of Portugal $(\times 1.2)$, France $(\times 2.0)$ and Italy $(\times 3.0)$, although the latter country defines the extra cost based upon the quality of the water (drinking quality), whereas the first two relate it to scarcity itself in a typical year. As mentioned, differentiated taxation regarding resource scarcity has attracted significant attention in some EU countries, as an instrument to help towards the internalization of environmental and resource costs. It should be borne in mind that calculations have been made based on an irrigated area of 5 hectares and an annual water use of $25,000 \mathrm{~m}^{3}$ or $15,000 \mathrm{~m}^{3}$ for the region of Puglia (Italy). Exemptions are made for annual water withdrawals less than $10,000 \mathrm{~m}^{3}$ in France and for users with power capacity below $3.7 \mathrm{~kW}$ for irrigation systems in Portugal. Differences exist between zones across as well as within the countries analysed. As mentioned, Spain appears to apply the highest tariff charges (through RBA tariffs) for irrigation water use compared to other southern EU countries. The rate of collection efficiency depends on the instrument used and quality of census. In the case of Spain, the RBAs consulted claim to collect $100 \%$ of the tariffs issued to irrigation users, but unfortunately, access to this information in the rest of the analysed countries is unavailable.

\section{Analysis of abstraction water tax in northern EU}

The analyses of the evolution of water tax in two water-abundant countries, such as Germany (case of Baden-Württemberg) and the Netherlands, is thought-provoking as Figure 2 illustrates. The histories of this instrument in these two countries have the following characteristics in common:

- Creation of a tax for the abstraction of water (general in Baden-Württemberg) and for groundwater in the Netherlands, defined as a volumetric $\left(E U R / \mathrm{m}^{3}\right)$ instrument. 

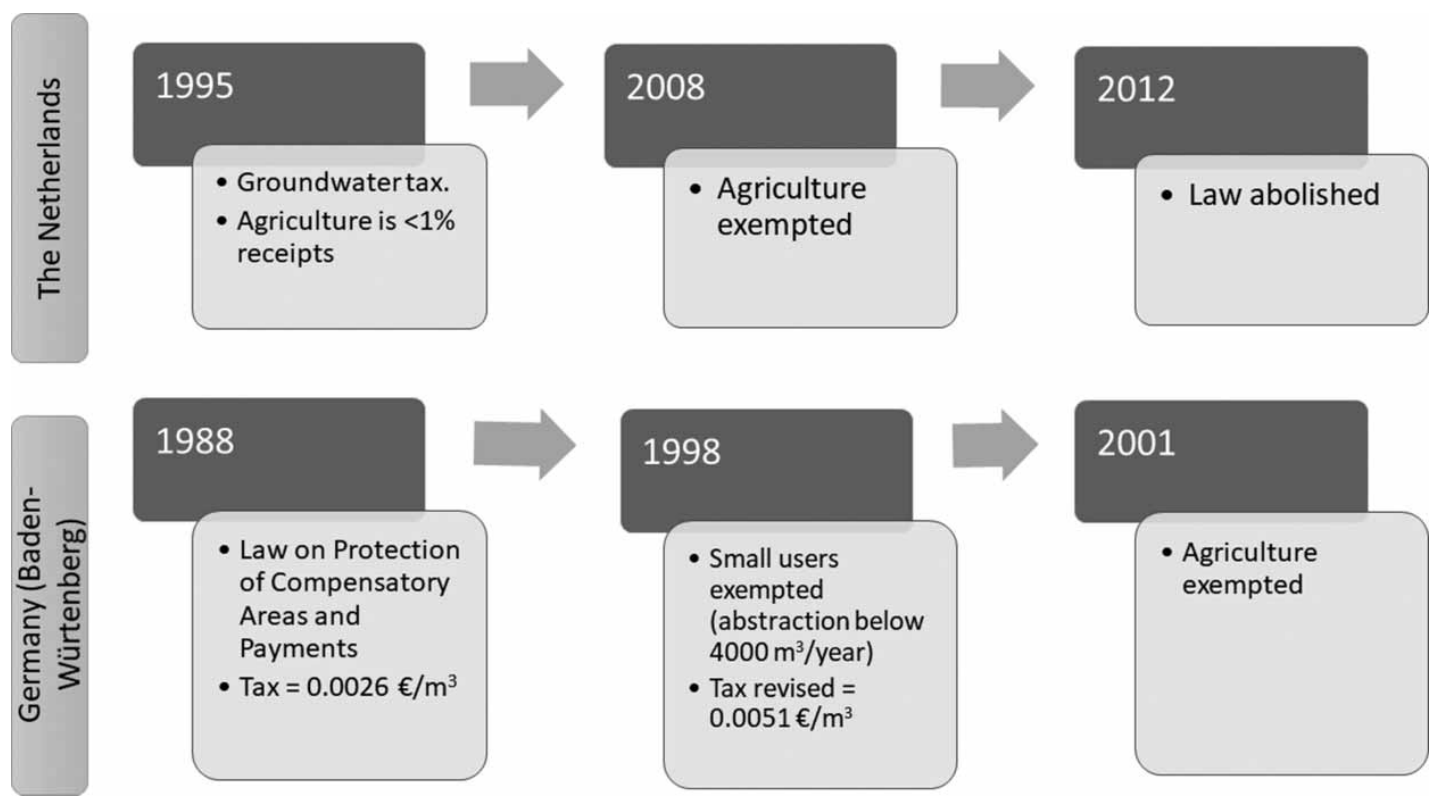

Fig. 2. Water abstraction taxes in Germany and the Netherlands. Source: Authors' own.

- Early adoption of groundwater and abstraction tax as a response to the 'green fiscal policy' movement in the 1980s and 1990s.

- Agriculture faces a lower tax than urban and industry sectors, and small farmers are totally exempted.

- Total agricultural exemption in 2001 (Germany) and 2008 (the Netherlands). In the Dutch case, GWT was finally abolished in December 2012.

Although the Dutch GWT is often cited as an example of environmental economics in action, the government revoked the tax on groundwater abstractions due to its inefficiency and limited financial capacity (Schuerhoff et al., 2013). Möller-Gulland et al. (2015) provide a detailed description of the case of the taxation scheme in Baden-Württemberg (Germany) that has suffered from the same shortcomings and also abolished in 2011.

\section{The issue of cost-sharing between sectors}

An important and usually neglected issue involves how to design the formula (or rule) used within the taxation system for cost-sharing between sectors regarding regulation costs of water resources (mainly surface waters). Administrations producing multiple services to different sectors need to make critical decisions regarding the pricing of the services provided; in our case, these are abstraction taxes and service tariffs. The methodology to avoid cross-subsidization should be based on a rational cost distribution that considers multiple factors, such as social factors (e.g., human needs) and technical factors (e.g., supply guarantee).

An example of joint cost allocation is provided by a multipurpose reservoir, which serves different policy goals: flood control, hydro-electric power, navigation, irrigation, municipal supply and/or 
industrial cooling. As Young (1985) explains, the cost function associated with such a problem typically exhibits decreasing marginal costs and the water resource planning problem is how to allocate the costs between the different purposes. Young (1985) dates back this problem to the creation of the Tennessee Valley Authority (TVA) in the 1930s, and concludes that certain cost-allocation formulas suggested for the TVA system are still in use today by water resource agencies even though this allocation rule was not based on any mathematical formula, but instead on judgement.

In the case of Spain and Portugal, it is therefore not surprising that the cost-distribution formula for RBA tariffs is based on the ratio 1:3 between irrigation and municipal uses, respectively. It is also worthy of note that this rule is considered by Spanish authorities based upon a normative that dates back to 1960 and is justified according to the 'potential benefits'; the justification in the case of Portugal is based on the 'higher guarantee of urban users'. In the French case, there is no clear justification for the matter-of-fact decision to use different weights to charge different services. Table 7 summarizes the different cost-allocation ratios between competing sectors in these three countries.

The issue of supply guarantee and priority use under drought events frequently appears in regions subject to water scarcity and cyclical droughts. Under scarcity conditions, urban users seldom suffer from any water restrictions, while irrigators face irrigation quota reductions in the case of water scarcity problems and periods of drought. In Spain, according to the Water Act, users must be guaranteed a supply guarantee around $99.8 \%$ for urban users (only $0.2 \%$ of supply breakdown is allowed), meanwhile guarantee level for irrigation is $90 \%$ (Ministry of Environment, 2008). Analysis of the real cost of water supply guarantee and the valuation of this service characteristic remains scarce; examples include the analysis of water trade in the region of Victoria (Australia), where the value for water entitlements with a high guarantee is $0.16 \mathrm{AUSD} / \mathrm{m}^{3}$ compared to water entitlements with a low guarantee at $0.08 \mathrm{AUSD} / \mathrm{m}^{3}$, which implies a ratio of high vs. low guarantee of $200 \%$ (Carr et al., 2015). Generally, Australian urban supply has a higher priority over irrigation and does not enter into competition with the irrigation water market. Based upon contingent valuation, Mesa-Jurado et al. (2012) found a willingness to pay (WTP) for the improvement from no guarantee (unregulated river) to a low-level guarantee in irrigated olive groves in Southern Spain of $0.029 \mathrm{EUR} / \mathrm{m}^{3}$, and of $0.074 \mathrm{EUR} / \mathrm{m}^{3}$ for the improvement from low-level to general guarantee (250\% mark-up in premium price).

In our opinion, the call for the development of a methodology for cost-sharing of multipurpose water infrastructure and water services has become one of great urgency. This methodology should consider the supply guarantee (estimated failure rate), the water quality and the frequency of service (daily vs. seasonal) as determining factors while avoiding cross-subsidies or at least making such subsidies more transparent. Moreover, governance and stakeholders' cooperation can be enhanced with the use of water fiscal instruments to allocate service provision costs in a more equative and efficient way. The integration of supply-guarantee cost-sharing in the water pricing system (through the definition

Table 7. Cost allocation of RB public water management services in three EU countries.

\begin{tabular}{lllll}
\hline Irrigation $=100 \%$ & Urban & Industry & Cooling & Source \\
\hline Spain & $300 \%$ & $300 \%$ & $30 \%$ & R.D.144 (1960) and MIMAM (2007) \\
Portugal & $300 \%$ & $250 \%$ & $4 \%$ & $\begin{array}{l}\text { Plano de Gestao de Regiao Hidrogeográfica Guadiana (RH7), APA (2016) } \\
\text { France }\end{array}$ \\
& $446 \%$ & $446 \%$ & $113 \%$ & $\begin{array}{c}\text { Délibération no. 2016 - 33 du 30-sep - 2016 (Agence de l'eau Rhône } \\
\text { Méditerranée) }\end{array}$
\end{tabular}

Source: Authors' own. 
of priorities during the planning process) is more feasible from a socio-political perspective compared with the alternative of using water pricing to allocate water during periods of scarcity, since farmers' income is already diminished during drought periods.

\section{Discussion and concluding remarks}

Water depletion and overexploitation is growing worldwide, casting significant doubt on the sustainable management of irrigation water in certain locations, such as southern Europe (Wada \& Bierkens, 2014). Among other policy instruments, taxation of water services may contribute towards the rationalization of the use of water resources (EEA, 2000, 2013) and the attainment of financial resources for policy-making while avoiding exemptions in environmental taxation considered to be a source of economic inefficiency (Ekins, 1999).

The implementation report carried out in March 2015 by the European Commission on the Programme of Measures in EU states showed very timid advances in the establishment of an appropriate water pricing policy (according to Art. 9 of the WFD) for agriculture in the implementation of the 2nd RBMPs (EC, 2015). Only some countries, such as France, Ireland, Italy, Luxembourg, Poland, Portugal, Romania and the United Kingdom, had introduced specific measures in this regard. Therefore, further and stronger efforts are necessary in EU states to provide adequate incentives for efficient water use in this sector. Again, this report highlighted the need to cover both water provision and self-abstraction services and the implementation of cost-recovery instruments of financial, environmental and resource costs associated with these services.

Irrigation water is generally exempted from taxation in countries where water is abundant, and even in certain water-scarce countries, a number of water sources are exempted (e.g., groundwater in Spain). As we have seen, Germany (Baden-Württemberg) and the Netherlands have introduced a water abstraction tax, yet they have both exempted irrigation, while southern countries (Portugal, Italy and France) have established a largely symbolic irrigation water tax to internalize environmental and resource costs. The exception in the southwestern EU is Spain, where RBA tariffs are higher than the other three countries, although, with few exceptions, groundwater use incurs no tax (Berbel et al., 2018). This is paradoxical since groundwater is used generally for higher-value crops compared to those of surface water, thus resulting in an average economic water productivity of over $3 \mathrm{USD} / \mathrm{m}^{3}$, compared with $1 \mathrm{USD} / \mathrm{m}^{3}$ for surface water (Shah, 2014). Moreover, seawater intrusion is a serious problem along the Mediterranean coasts and in other coastal areas around the world, where the water demands of tourism and agriculture constitute the leading cause of groundwater overexploitation (Giannoccaro et al., 2017).

The taxes in France, Italy and Portugal included additional charges in those locations with water overexploitation or scarcity problems (France and Portugal) or with water of drinking quality (Italy). The application of this premium price mainly strives to internalize resource scarcity costs and aims to induce water savings. However, the combined use of the abstraction tax with the RBA service tariffs may lead to concentrate these reallocation and saving effects on commodities and low-value crops.

In this same vein, several European institutions highlight the effectiveness of water taxation as an instrument to achieve the sustainable use of water resources (EEA, 2000; EC, 2012), and water pricing is seen as a means to promote water reallocation in order to free up water for non-agricultural uses (Molle \& Berkoff, 2006). In contrast, other authors point towards certain limitations in the implementation of water pricing instruments regarding water saving since the reduction of water withdrawals does 
not necessarily lead to 'real' water savings (Schuerhoff et al., 2013). Various studies have found low elasticity in irrigation water demand, mostly in the case of high-value crops (Scheierling et al., 2006; Expósito \& Berbel, 2016), which hampers the effectiveness of water pricing in reducing irrigation water consumption. Nevertheless, despite said low elasticities, water pricing may act as a reallocation mechanism within the agriculture sector due to the significant volume of irrigation required for certain crops (e.g., maize and rice). Additionally, water pricing measures may imply a substantial revenue-raising potential (EC, 2012). On the other hand, the costs incurred in metering and control services for the implementation of volumetric pricing schemes to self-supply users are very high (Ursitti et al., 2018).

Although the use of economic instruments, such as fiscal instruments, can contribute towards addressing water quantity and quality problems, it is worth noting that economic instruments for water management are no substitute for conventional command-and-control and supply policies; rather, they should be designed to complement said policies. Indeed, an optimal water policy mix should include various instruments from both the supply and demand sides, including economic and non-economic instruments. Therefore, a suitable water governance framework should be based on the use of a mix of water policy and management instruments, together with feasible institutional reforms and the necessary investments from public and private sectors. Additionally, the participation of all involved stakeholders must be taken into account in water policy design, since collective action initiatives have become a relevant instrument for sustainable governance of water resources. Furthermore, governance frameworks should be tailored to specific countries and regions (e.g., river basins), whereby their specific socio-economic, agronomic and climatic conditions need to be considered.

Nevertheless, the rather limited progress in the use of economic instruments aimed at achieving a more sustainable (and eco-friendly) use of water resources in the European irrigation sector gives the impression that studies therein are characterized by good intentions and rhetoric rather than practice. Along these lines, economic instruments such as water taxation and market-based instruments (e.g., water trading, water banks) are still weakly (if at all) implemented within EU countries. This is also related to the difficulties encountered by national governments in the establishment of reliable environmental accounting systems, especially for the irrigation water sector.

An additional explanation of the difficult treatment of agriculture as any other industry is what is called 'Agricultural Exceptionalism', that can be found in many dominions, such as labour regulations (Luna, 1997), water quality protection (Pollans, 2016), subsidies and trade protection (Daugbjerg \& Swinbank, 2008) and VAT normative reducing tax burden for farmers compared to the rest of economic sectors (Gómez-Limón \& Berbel, 1994), to quote some examples. Montpetit (2002) explains this exceptionalism based upon the 'protected development paradigm' consequence of a combination of past policy decisions with strong policy networks. This combination of past and present constraints acts in limiting government action and may explain the observed trajectories of Dutch and German water taxes. Regarding the recent introduction of water abstraction taxes in Portugal, Italy or France, the level of taxation is still low and no significant sectoral opposition has been observed. Nevertheless, as previously noted, water taxation cannot be the only measure to guarantee the sustainable use of water resources and the abatement of pollution and of other environmental negative externalities. In this respect, the engagement of all implied stakeholders and the promotion of collective action initiatives have shown positive outcomes in the reduction of diffuse water pollution from agricultural activities (Esteban \& Albiac, 2012).

Water use for irrigation is likely to increase across the globe in coming years, which will lead to critical overexploitation in more places, with the most difficult source to control being groundwater in arid 
regions (e.g., Mediterranean region, south-western and central USA, north China) (Wada \& Bierkens, 2014). Many studies, such as those by Gleick et al. (2011), Kummu et al. (2014) and Wada \& Bierkens (2014), argue that, in order to prevent extreme water-scarcity problems, a combination of innovative water technologies, governance measures and economic instruments will be required. In the case of 'closed' river basins, as is the case in many areas in southern Europe (e.g., Guadalquivir in southern Spain), differentiated irrigation-water taxation schemes (both for surface and ground waters) could provide an instrument to alleviate the over-allocation of available resources.

In summary, countries with similar climatic and hydrological conditions to those of Spain but with different levels of water scarcity (such as Portugal, France and Italy) have implemented abstraction taxes to induce a more sustainable use of water resources and to cover service costs supported by water agencies. In contrast, northern European countries (such as the Netherlands, Germany and Denmark) do not currently have any tax instrument to recover water service costs related to irrigation water use (neither surface water nor groundwater). Finally, despite the need for more transparent and incentivizing pricing measures in irrigation as stated by certain institutions (OECD, 2010b; EC, 2012), small and contradictory steps have been taken in the EU over the last decade. The outcomes of current experiences in the selected EU countries require further research in order to analyse the dynamic effects of these taxation schemes on irrigators' behaviour and social welfare.

\section{References}

Agence de l'eau Rhône Méditerranée (2016). Conseil d'Administration Seance. Extraits Conformes des Deliberations no. 2016-33. (Board of Directors Seance. Compliant Extracts from Deliberations) France.

Agencia Portuguesa Do Ambiente (2016). Plano de Gestao de Regiao Hidrogeográfica. Parte 7- Sistema de Promocao Acompanhamento e Avaliacao. Regia Hidrografica do Guadiana (RH7). (Hydrogeographic Region Management Plan. Part 7 Promotion System Monitoring and Evaluation. Guadiana Hydrographic Region) Portugal.

Albiac, J. (2017). Review on the Political Economy of Water Reforms in Agriculture. Working Document 17/01, Department of Agricultural Economics, Regional Government of Aragon, Spain.

ARCADIS (2012). The Role of Water Pricing and Water Allocation in Agriculture in Delivering Sustainable Water use in Europe. Project number 11589. European Commission, Brussels, Belgium.

Bass, K. \& Graveland, C. (2011). Living with water: not without water statistics. In: 58th World Statistical Congress, Dublin, Ireland, pp. 1437-1458.

Berbel, J. \& Expósito, A. (2018). Economic challenges for the EU Water Framework Directive reform and implementation. European Planning Studies 26(1), 20-34.

Berbel, J., Expósito, A. \& Borrego-Marín, M. M. (2018). Conciliation of competing uses and stakeholder rights to groundwater: an evaluation of Fuencaliente aquifer (Spain). International Journal of Water Resources Development.

Berbel, J., Expósito, A., Gutiérrez-Martín, C. \& Mateos, L. (2019). Effects of the irrigation modernization in Spain $2002-2015$. Water Resources Management 33.

BMUB (2016). Water Framework Directive - The Status of German Waters 2015. Umweltbundesamt, Dessau, Germany.

BOE (2001). Real Decreto Legislativo 1/2001, de 20 de Julio, por el que se Aprueba el Texto Refundido de la Ley de Aguas. Boletín Oficial del Estado no. 176, de 24/07/2001. (Royal Legislative Decree 1/2001, of July 20, approving the revised text of the Water Law).

Borrego-Marín, M. M., Gutiérrez-Martín, C. \& Berbel, J. (2016). Estimation of cost recovery ratio for water services based on the system of environmental-economic accounting for water. Water Resources Management 30(2), 767-783.

Carr, R., Arold, N. \& Chees, J. (2015). Water Entitlement Market Prices Murray-Darling Basin 2015. Marsden Jacob Associates, Melbourne, Australia.

Daugbjerg, C. \& Swinbank, A. (2008). Curbing agricultural exceptionalism: the EU's response to external challenge. World Economy 31(5), 631-652. 
Diário da República (2008). Decreto-Lei no. 97/2008 de 11 de junho. Diário da República, 1. ${ }^{\text {a }}$ série - No. 111-11 de junho de 2008, Portugal.

Diário da República (2017a). Decreto-Lei no. 46/2017 de 3 de maio. Diário da República, 1. ${ }^{a}$ série - No. 85-3 de maio de 2017, Portugal.

Diário da República (2017b). Despacho no. 3025/2017 de 11 de abril de 2017. Diário da República, 1. a série - No. 72-11 de abril de 2017, Portugal.

Ekins, P. (1999). European environmental taxes and charges: recent experience, issues and trends. Ecological Economics 31(1), 39-62.

Esteban, E. \& Albiac, J. (2012). Assessment of nonpoint pollution instruments: the case of Spanish agriculture. International Journal of Water Resources Development 28(1), 73-88.

European Commission (2000). Directive (2000/60/EC) Water Framework Directive of the European Parliament and of the Council. OJ L, pp. 1-73, Brussels, Belgium.

European Commission (2003). Economics and the Environment: the Implementation Challenge of the Water Framework Directive. WATECO: a guidance document, Brussels, Belgium.

European Commission (2010). Europe 2020. A European Strategy for Smart, Sustainable and Inclusive Growth. Brussels, Belgium

European Commission (2012). A Blueprint to Safeguard Europe's Water Resources. Communication From the Commission to the European Parliament, the Council, the European Economic and Social Committee and the Committee of the Regions. COM (2012) 673 Final. European Commission, Brussels, Belgium.

European Commission (2015). Water Framework Directive and the Floods Directive: Actions Towards the 'Good Status' of EU Water and to Reduce Flood Risks. Report on the Progress in Implementation of the Water Framework Directive Programmes of Measures. SWD (2015) 50 Final. Brussels, Belgium.

European Environment Agency (2000). Environmental Taxes: Recent Development in Tools for Integration. Environmental Issues Series, No.18. European Environment Agency (EEA), Copenhagen, Denmark.

European Environment Agency (2011). Environmental tax Reform in Europe, Opportunities for eco-Innovation. EEA Report 17/2011. European Environment Agency (EEA), Copenhagen, Denmark.

European Environment Agency (2013). Towards A Green Economy in Europe. EU Environmental Policy Targets and Objectives 2010-2050. EEA Report, No.8. European Environment Agency (EEA), Copenhagen, Denmark.

European Environment Agency (2016). Environmental Taxation and EU Environmental Policies. European Environment Agency (EEA), Copenhagen, Denmark.

Eurostat. (2010). Europe in Figures. Eurostat Yearbook 2010. European Union, Brussels, Belgium.

Expósito, A. \& Berbel, J. (2016). Why is water pricing ineffective for deficit irrigation schemes? A case study in Southern Spain. Water Resources Management 31(3), 1047-1059.

Gawel, E. (2014). Article 9 of the EU water framework directive: do we really need to calculate environmental and resource costs? Journal for European Environmental \& Planning Law 11(3), 249-271.

GEUS (2010) Water Supply in Denmark. Denmark.

Giannoccaro, G., Scardigno, A. \& Prosperi, M. (2017). Economic analysis of the long-term effects of groundwater salinity: bringing the farmer's perspectives into policy. Journal of Integrative Environmental Sciences 14(1), 59-72.

Gleick, P. H., Christian-Smith, J. \& Cooley, H. (2011). Water-use efficiency and productivity: rethinking the basin approach. Water International 36(7), 784-798.

Gómez-Limón, J. A. \& Berbel, J. (1994). Análisis de la neutralidad global del régimen especial del IVA para la agricultura en su aplicación en España y la Comunidad Andaluza. (Analysis of the global neutrality of the special VAT regime for agriculture in its application in Spain and the Andalusian Community). Revista Española de Economía Agraria 170, 233-264.

JORF (2016). Loi $n^{\circ}$ 2016-33 du 30 septembre 2016 du conseil d'administration de l'agence de l'eauRhône Méditerranée Corse sur les zones de tarification de la redevance pour prélèvement sur la ressource en eau et les taux de redevance pour les années 2017 et 2018. (Law No. 2016-33 of September 30, 2016 of the board of directors of the MediterraneanCorsica water agency on the charging zones for the levy on the water resource and the royalty rates for the years 2017 and 2018) JORF no. 0244 du 19 Octobre 2016 texte no. 92, France.

Kummu, M., Gerten, D., Heinke, J., Konzmann, M. \& Varis, O. (2014). Climate-driven interannual variability of water scarcity in food production potential: a global analysis. Hydrology and Earth System Sciences 18(2), 447-461. 
Luna, G. T. (1997). An infinite distance: agricultural exceptionalism and agricultural labor. U. Pa. Journal of Labor and Employment Law 1, 487-510.

Mesa-Jurado, M. A., Martin-Ortega, J., Ruto, E. \& Berbel, J. (2012). The economic value of guaranteed water supply for irrigation under scarcity conditions. Agricultural Water Management 113, 10-18.

Ministry of Environment (2007). Precios Y Costes de los Servicios del Agua en España. (Prices and Costs of Water Services in Spain). Madrid, Spain.

Ministry of Environment (2008). Orden ARM/2656/2008, de 10 de septiembre, por la que se aprueba la Instrucción de Planificación Hidrológica. (Hydrological Planning Instruction) BOE no. 229, Madrid, Spain.

Molle, F. \& Berkoff, J. (2006). Cities Versus Agriculture: Revisiting Intersectoral Water Transfers, Potential Gains, and Conflicts. Comprehensive Assesment Research Report 10. International Water Management Institute, Colombo, Sri Lanka.

Möller-Gulland, J., Lago, M., McGlade, K. \& Anzaldua, G. (2015). Effluent tax in Germany. In: Use of Economic Instruments in Water Policy: Insights From International Experience. Lago, M., Mysiak, J., Gómez, C. M., Delacámara, G. \& Maziotis, A. (ed.). Springer, Cham, Switzerland, pp. 21-38.

Montpetit, É. (2002). Policy networks, federal arrangements, and the development of environmental regulations: a comparison of the Canadian and American agricultural sectors. Governance 15(1), 1-20.

OECD (Organisation for Economic Co-operation and Development) (2010a). Agricultural Water Pricing: EU and Mexico. OECD, Paris, France.

OECD (Organisation for Economic Co-operation and Development) (2010b). Sustainable Management of Water Resources in Agriculture. OECD Publishing, Paris, France.

Pollans, M. J. (2016). Drinking water protection and agricultural exceptionalism. Ohio State Law Journal 77(6), 1195-1260.

Scheierling, S. M., Loomis, J. B. \& Young, R. A. (2006). Irrigation water demand: a meta-analysis of price elasticities. Water Resources Research 42(1), W01411.

Schuerhoff, M., Weikard, H. -P. \& Zetland, D. (2013). The life and death of Dutch groundwater tax. Water Policy 15(6), 1064-1077.

Shah, M. (2014). Groundwater Governance and Irrigated Agriculture. Technical Committee (TEC) Background Papers 19. Global Water Partnership, Stockholm, Sweden.

Ursitti, A., Giannoccaro, G., Prosperi, M., De Meo, E. \& de Gennaro, B. ((2018)). The magnitude and cost of groundwater metering and control in agriculture. Water 10(3), 344.

Viaggi, D., Raggi, M., Bartolini, F. \& Gallerani, V. (2010). Designing contracts for irrigation water under asymmetric information: are simple pricing mechanisms enough? Agricultural Water Management 97(9), 1326-1332.

Wada, Y. \& Bierkens, M. F. P. (2014). Sustainability of global water use: past reconstruction and future projections. Environmental Research Letters 9(10), 104003.

Young, H. P. (1985). Cost Allocation: Methods, Principles, Applications. North Holland Publishing Co., Amsterdam, The Netherlands.

Zucaro, R., Pontrandolfi, A., Dodaro, G. M., Gallinoni, C., Pacicco, C. L. \& Vollaro, M. (2011). Atlante Nazionale Dell'irrigazione. (National Atlas of Irrigation) INEA 34/5000, Rome, Italy.

Received 26 September 2018; accepted in revised form 6 March 2019. Available online 11 April 2019 